\title{
The WTO Disciplines and Trade in Products Powered by Artificial Intelligence: Old Wine and New Wine-skin?
}

\section{Lei Zhang* \& Kelly K. Shang**}

As goods and services powered by AI continue to proliferate, scholarly opinion seems to consider that current WTO law is insufficient to regulate trade in AI-powered products. The following reasons can help explain this perceived insufficiency of the WTO law: (a) AI-powered products are difficult to categorise within the perceived goods/services dichotomy under WTO law, thus causing uncertainties as to the applicable legal regime; and (b) the WTO law has yet to respond to the need for national governments to strike a balance between trade and controversial trade practices regarding AI-powered products. This paper argues that while current WTO law is far from perfect, it does partly regulate trade in AI-powered products. The following observations substantiate the partial regulation of trade in AI-powered products by the WTO law: (a) AI-powered products cannot escape existing WTO disciplines on trade in goods and trade in services, by virtue of either the involvement of AI or the perceived goods/services dichotomy; and (b) efforts to balance trade/non-trade interests associated with trade in AI-powered products are allowed under the GATT/GATS' 'public morals' and security exceptions.

\section{Keywords}

Artificial Intelligence, Al, WTO Law, Trade in Al-powered Products

* Dean of WTO Chair Institute-China; Dean of School of Trade Negotiations, and Director of Shanghai Centre for Global Economic and Trade Governance, Shanghai University of International Business and Economics. Ph.D. (SUIBE). The author may be contacted at: wtozhanglei@suibe.edu.cn/Address: 620 Gubei Road, Shanghai 200336 P.R. China.

** Lecturer at Shanghai University of International Business and Economics; Fellow of the World Trade Institute (WTI) at the University of Bern. J.D. (St. John's College, Hong Kong), Ph.D. (Maastricht). The author may be contacted at: kellyshang. nl@gmail.com/Address: 100 Royal Parade, Melbourne VIC 3000, Australia. She gives thanks to Ms. Rachel R Du, Master of Advanced Studies in International Law and Economics (MILE) Candidate, WTI for her research assistance. 


\section{Introduction}

In recent years, main trading economies including China, ${ }^{1}$ the European Union ("EU") $)^{2}$ and the United States ("US") ${ }^{3}$ have incorporated the development of artificial intelligence ("AI") into their national strategies. Regional trade agreements including the United States-Mexico-Canada Agreement ("USMCA"), the Comprehensive and Progressive Agreement for Trans-Pacific Partnership (“CPTPP”), and the EU's Regulation on the Free Flow of Non-personal Data ${ }^{4}$ further included certain provisions that regulate some aspects of international trade regarding the development and use of AI.

Nevertheless, no international (as opposed to regional) disciplines at present seem to explicitly regulate international trade activities regarding the development and trade in AI-powered products. ${ }^{5}$ The apparent absence of effective international

1 Notice of the State Council on Issuing the Development Plan on the New Generation of Artificial Intelligence [国务院 关于印发新一代人工智能发展规划的通知], Guofa [国发] [2017] No 35 (2017). See also R. HAss \& Z. BALIN, USChina Relations in the Age of Artificial Intelligence (2019), available at https://www.brookings.edu/research/uschina-relations-in-the-age-of-artificial-intelligence (last visited on Apr. 23, 2019).

2 European Commission, Communication from the Commission to the European Parliament, the European Council, the Council, the European Economic and Social Committee and the Committee of the Regions: Artificial Intelligence FOR EUROPE 2 (2018), available at https://eur-lex.europa.eu/legal-content/EN/TXT/PDF/?uri=CELEX:52018DC0237\& from=EN. (It states that "European leaders have put AI at the top of their agendas.") See also THE (SWEDISH) NATIONAL Board of Trade, How Borderless is the Cloud?: An Introduction to Cloud Computing and International Trade (2012), available at https://www.kommers.se/In-English/Publications/2012/How-Borderless-is-the-Cloud (all last visited on Apr. 23, 2019).

3 See Artificial Intelligence for the American People (Fact Sheet), The White House Briefing (2018), available at https:// www.whitehouse.gov/briefings-statements/artificial-intelligence-american-people. For details, see M. MULVANEY \& M. Kratsios, Memorandum for the Heads of Executive Departments and Agencies: Fy 2020 Administration Research and Development Budget Priorities (2018), available at https:/www.whitehouse.gov/wp-content/uploads/ 2018/07/ M-18-22.pdf; National Science and Technology Council-Networking and Information Technology Research and Development Subcommittee, The National Artificial Intelligence Research and Development Strategic Plan (2016), available at $\mathrm{https}$ //www.nitrd.gov/PUBS/national_ai_rd_strategic_plan.pdf; EXECUTIVE OFFICE OF THE PrESIDENT - National Science and Technology Council Committee on Technology, Preparing for the Future of Artificial INTELLIGENCE (2016), available at https://obamawhitehouse.archives.gov/sites/default/files/whitehouse_files/microsites/ ostp/NSTC/preparing_for_the_future_of_ai.pdf; Executive Office of the President, Big Data: Seizing Opportunities, PRESERVING VAlues (2014), available at https://obamawhitehouse.archives.gov/sites/default/files/docs/20150204_Big _ Data_Seizing_Opportunities_Preserving_Values_Memo.pdf (all last visited on Apr. 23, 2019).

4 Regulation of the European Parliament and of the Council on A Framework for the Free Flow of Non-Personal Data in the European Union, Oct. 17, 2018, art 4 \& pmbl.q 1, available at https://eur-lex.europa.eu/legal-content/EN/TXT/HT ML/?uri=CELEX:32018R1807\&from=EN (last visited on Apr. 23, 2019).

5 The term 'product' in this paper is defined to include both goods and services; this is consistent with the Appellate Body's approach in defining the term 'product' in China-Publications and Audiovisual Products (2009). See Appellate Body Report, China - Measures Affecting Trading Rights and Distribution Services for Certain Publications and Audiovisual Entertainment Products, ๆ 364, WTO Doc. WT/DS363/AB/R (adopted Jan.19, 2010), available at https:// 
disciplines relating to AI-powered products, as exemplified by the somewhat outdated treaty language used in the WTO agreements, has raised scholarly concerns. ${ }^{6}$ Some scholars have further highlighted the need for AI-related trade disciplines. ${ }^{7}$

What remains unclear from existing research, however, is the extent to which existing WTO disciplines can be relevant to trade in AI-powered products. A closer scrutiny of the WTO law in this area is needed for two reasons. First, unless and until new trade disciplines that broadly (albeit not universally) apply to trading countries and regions are agreed to, the international community will need to cope with the somewhat unsatisfactory WTO disciplines currently in place as the only legal scheme that provides nearly universal coverage. Second, when (and if) the international community does negotiate new trade treaties, it would be beneficial for negotiators to start by reviewing existing disciplines with the hope of ascertaining what they have already agreed upon.

Accordingly, this research article attempts to address the following question: to what extent can current WTO law regulate trade in AI-powered products? In particular, this paper focuses on two issues: (a) to what extent are current GATT/ GATS principles on non-discrimination and market access relevant to trade in AIpowered products; and (b) whether existing WTO law is capable of maintaining any balance between trade liberalisation, on the one hand, and a range of non-trade values that its Members may seek to protect, on the other hand.

This paper is composed of five parts including Introduction and Conclusion. Part two will briefly introduce background knowledge regarding the definition, scope and possible use of AI. Part three will examine current WTO law that regulates trade in AI-powered products. Part four will explore the ways in which current AI-related WTO law can be clarified and developed, through either case law or new trade treaties. It further submits that although current WTO disciplines regarding trade in AI-powered products are far from perfect, they do offer some degree of regulation and can be used as a starting point for further disciplines to be negotiated and developed.

www.wto.org/english/tratop_e/dispu_e/cases_e/ds363_e.htm (last visited on Apr. 23, 2019).

6 See, e.g., M. Burri, The Governance of Data and Data Flows in Trade Agreements: The Pitfalls of Legal Adaptation, 51 U.C. Davis L. Rev. 65 (2017); R. Weber \& M. Burri, Classification of Services in the Digital Economy (2013).

7 See, e.g., S. Aaronson, Artificial Intelligence is Trade Policy's New Frontier (2018), available at https://www. cigionline.org/articles/artificial-intelligence-trade-policys-new-frontier (last visited on Apr. 23, 2019). See also A. Mitchell \& J. Hepburn, Don't Fence Me in: Reforming Trade and Investment Law to Better Facilitate Cross-Border Data Transfer, 19 YALE J.L. \& TECH. 182 (2017). (arguing that "existing rules of international trade and investment law do not protect cross-border data transfer in a consistent, coherent and predictable manner.") 


\section{Definition, Scope and Use of AI}

\section{A. Definition and Scope}

There does not seem to be any agreed definition of the term 'AI'. A 2016 US Government paper acknowledged such a lack of definition. ${ }^{8}$ A European Commission paper defined 'AI' in 2018 as "systems that display intelligent behaviour by analysing their environment and taking actions-with some degree of autonomy-to achieve specific goals." 9

The use of AI is very broad. The European Commission commented that AI provides the "most strategic technologies of the 21st century," comparable to "the steam engine or electricity in the past." 11 Technology at present can already allow AI to perform a range of duties, including: (a) simple duties that "make life easier," such as operating voice assistants in mobile phones or driving self-driving vehicles; ${ }^{12}(\mathrm{~b})$ duties that increase commercial productivity, such as running farms or providing financial services; ${ }^{13}$ (c) duties that limit civil liberties, ${ }^{14}$ such as profiling or operating 'social credit' systems; ${ }^{15}$ and (d) duties involving military (or dual-use) purposes. ${ }^{16}$

8 Executive Office of the President - National Science and Technology Council Committee on Technology, supra note 3 , at 6 . (stating that "[t] here is no single definition of AI that is universally accepted by practitioners. Some define AI loosely as a computerized system that exhibits behavior that is commonly thought of as requiring intelligence. Others define AI as a system capable of rationally solving complex problems or taking appropriate actions to achieve its goals in whatever real world circumstances it encounters.")

9 European Commission, supra note 2.

$10 \quad I d$. at 2.

11 Id.

12 Id.

13 Id.

14 Id.

15 See, e.g., B. Marr, Chinese Social Credit Score: Utopian Big Data Bliss or Black Mirror on Steroids?, Forbes, Jan. 21, 2019, available at https:/www.forbes.com/sites/bernardmarr/2019/01/21/chinese-social-credit-score-utopian-big-databliss-or-black-mirror-on-steroids. (reviewing China's 'social credit' system). See also J. Horsley, China's Orwellian Social Credit Score Isn't Real, ForeIGN PoL'y, Nov. 16, 2019, available at https://foreignpolicy.com/2018/11/16/ chinas-orwellian-social-credit-score-isnt-real (all last visited on Apr. 23, 2019).

16 See, e.g., The (US) Department of Defense, Summary of the 2018 National Defense Strategy of the United States of AmErica 6 (2018). (stating that "[t]he Department [of Defense] will invest broadly in military application of autonomy, artificial intelligence, and machine learning.") See also The (US) Department of Defense, Summary of the 2018 Department of Defense Artificial Intelligence Strategy - Harnessing Ai to Advance Our Security and ProsPerity (2019), available at https://media.defense.gov/2019/Feb/12/2002088963/-1/-1/1/SUMMARY-OF-DODAI-STRATEGY.PDF; EUROPEAN COMMISSION, supra note 2 at 20. (arguing that 'the power of AI [should be placed] at the service of human progress'); G.Webster et al., China Plan to Lead in AI: Purpose, Prospects, and Problems (2017), available at https://www.newamerica.org/cybersecurity-initiative/blog/chinas-plan-lead-ai-purpose-prospectsand-problems (all last visited on Apr. 23, 2019). (arguing that "Chinese leadership wants to ensure that advances in 
Many AI technologies are supported by or trained with data which is described as "the raw material for AI"17 needed to improve their performance. ${ }^{18}$ Accordingly, the $\mathrm{EU}$ and the US seem to be committed to achieving a freer flow of data ${ }^{19}$ so as to assist with their development of AI.

\section{B. Controversial Practices regarding the Development and Use of AI-powered Products}

AI-powered products may attract controversy internationally in various ways. First, AI-powered products may become controversial due to the way in which they are developed. For example, a WTO Member may set up a domestic policy that enables AI-developers to collect data aggressively. In particular, a WTO Member may: (a) maintain an artificially weak mechanism of data privacy protection so as to "allow its data aggregators a freer hand in what they can do with what they collect"; ${ }^{20}$ (b) use State power to collect personal data and 'feed' such data to its private companies. In either of these scenarios, AI developers within this Member are provided with easier and less expensive access to data to 'train' their AI at the expense of their citizens' privacy rights. Its AI developers consequently gain a comparative advantage in their end-products over 'like' goods or services from other WTO Members that do not subscribe to such practices. Second, AI-powered products may attract controversy due to the way in which they are used. Controversial uses of AI-powered products include the use of AI for surveillance, social profiling, ${ }^{21}$ and operating 'social credit' systems.

In each of the above circumstances, an importing Member that does not subscribe to the moral or policy view of the producing Member may choose to set import barriers against any product powered by controversial AI. Accordingly, one may ask: Does the WTO law allow Members to restrict the import of goods or services on the

AI can be leveraged for national defense, through a national strategy for military-civil fusion.") See also J.-G. Castel \& M. Castel, The Road to Artificial Super Intelligence: Has International Law a Role to Play?, 14 CAN. J. L. \& TECH. 14 (2016). (arguing that "international law has an important role to play in programming and controlling [fully autonomous super-intelligent] machines.")

17 European Commission, supra note 2, at 3.

18 Id. at 2 .

19 Id. at 1. (arguing that "[a]mid fierce global competition, a solid European [AI] framework is needed.")

20 See, e.g., N. Thompson \& I. Bremmer, The AI Cold War that Threatens Us All, WIRED, Oct. 23, 2018, available at https://www.wired.com/story/ai-cold-war-china-could-doom-us-all (last visited on May 28, 2019).

21 M. Evans, Artificial intelligence tool used to catch people who lie to the police, TeLEGRAPH, Jan. 7, 2019, available at https://www.telegraph.co.uk/news/2019/01/07/artificial-intelligence-tool-used-catch-people-lie-police (last visited on May 28, 2019). 
basis of a higher standard of moral or security concern that they subscribe to?

\section{Current WTO Disciplines regarding Trade in AI-powered Products}

\section{A. Are AI-powered Products Goods or Services?}

A starting point for examining the WTO law applicable to trade in AI-powered products is to identify whether such products are classified as goods or services under the WTO law. Such classification is important, since different WTO obligations (GATT/GATS) would apply to products depending on whether they are classified as goods or services. In this context, many writers have lamented the ambiguity ${ }^{22}$ or unreasonableness $^{23}$ of the WTO rules that classify products as goods or services. For instance, Fleuter argued, inter alia, that: (a) the WTO law warrants a clear goods/ services dichotomy; and (b) the test for goods is 'tangibility. ${ }^{24}$ Nevertheless, these criticisms seem to be based on an inaccurate understanding of current WTO law.

A closer study of the WTO case law suggests at least some guidelines regarding the goods/services distinction under the WTO law. First, it is clear under the WTO case law that there is no dichotomy between GATT 1994 and GATS obligations or, put differently, between the obligations that apply to goods and those that apply to services. For example, the Panel in Canada-Periodicals (1997) observed:

Overlaps between the subject matter of disciplines in GATT 1994 and in GATS are inevitable, and will further increase with the progress of technology and the globalization of economic activities ... [A]dvertising services have long been

22 S. Fleuter, The Role of Digital Products under the WTO: A New Framework for GATT and GATS Classification, 17 CHI. J. INT'L L. 162 (2016). (arguing that there is a "need for a neutral system to classify digital products," and that "existing literature ... has thus far failed to provide a positive framework for [the] classification of [digital products in international trade]").

23 Id. (arguing that current WTO law is unreasonable since "digital products should be treated the same as their physical analogs.")

24 Id. (arguing that "[o]ne common usage distinction often applied to goods and services is that goods are tangible while services are intangible"... "WTO Appellate Body decided that periodicals were a tangible product of ink and paper so they could not be classified as services.") See also Mitchell \& Hepburn, supra note 7, at 196. (arguing that in the context of measures relating to cross-border transfer of data, that such measures are "most likely to be examined under the GATS because digital data is usually transferred ... without requiring any transfer of physical commodities."); A. Mattoo \& L. Scbuknecht, Trade Policies for Electronic Commerce (Policy Research Working Papers) 17 (2000), available at http:// kavehh.com/my\%20Document/Essex/wto/Trade\%20policies\%20for\%20electronic\%20commerce.pdf (last visited on Apr. 23, 2019). (discussing the ambiguities in classifying electronically delivered products under the GATS). 
associated with the disciplines under GATT Article III ... [S] everal adopted [GATT] panel reports ... examined the issue of services in the context of GATT [1947] Article III ... ${ }^{25}$

In Canada - Periodicals, the Appellate Body ruled: "The entry into force of the GATS ... does not diminish the scope of application of the GATT 1994." ${ }^{26}$ The Appellate Body further 'agree[d] ${ }^{, 27}$ that the Panel's statement "indicates that obligations under GATT 1994 and GATS can co-exist and that one does not override the other." 28 The Appellate Body continued by stating:

We are unable to agree with Canada's proposition that the GATT 1994 is not applicable to [the disputed measure]. First of all, the measure is an excise tax imposed on split-run editions of periodical... not 'tax on advertising'. ... Secondly, a periodical is a good comprised of two components: editorial content and advertising content. Both components can be viewed as having services attributes, but they combine to form a physical product - the periodical itself. ${ }^{29}$

In EC-Bananas III (1997), the Appellate Body further affirmed the overlap between GATT 1994 and GATS obligations by ruling that:

There is ... a third category of measures that could be found to fall within the scope of both the GATT 1994 and the GATS. These are measures that involve a service relating to a particular good or a service supplied in conjunction with a particular good. In all such cases... the measure in question could be scrutinized under both the GATT 1994 and the GATS. However... the specific aspects of that measure examined under each agreement could be different. ${ }^{30}$

In China-Publications and Audiovisual Products (2009), the Appellate Body observed that "a measure can regulate both goods and services and that, as a result, the

25 Panel Report, Canada - Certain Measures Concerning Periodicals, WTO Doc. WT/DS31/R (adopted Jul. 30, 1997), I 5.18-5.19, available at https://www.wto.org/english/tratop_e/dispu_e/cases_e/ds31_e.htm (last visited on Apr. 23, 2019).

26 Appellate Body Report, Canada - Certain Measures Concerning Periodicals, WTO Doc. WT/DS31/AB/R (adopted July 30, 1997), ๆ 19, available at https://www.wto.org/english/tratop_e/dispu_e/cases_e/ds31_e.htm (last visited on Apr. 23, 2019).

27 Id.

28 Id. (referring to Panel Report, supra note 27 at 5.17.).

29 Id. 17.

30 Appellate Body Report, European Communities - Regime for the Importation, Sale and Distribution of Bananas, WTO Doc. WT/DS27/AB/R (adopted Sept. 25 1997), ๆ 221, available at https://www.wto.org/english/tratop_e/dispu_e/ cases_e/ds27_e.htm (last visited on Apr. 23, 2019). 
same measure can be subject to obligations affecting trade in goods and obligations affecting trade in services." 31

Second, it appears that not only does the WTO law reject a dichotomy between the disciplines that regulate goods and those that regulate services, but it also rejects a goods/services dichotomy. In China-Publications and Audiovisual Products (2009), China argued that one of its measures at issue affected only the right to import the 'intangible content' of films, but that it did not relate to "the physical carrier of such content." ${ }^{, 32}$ Such an argument was rejected by the Appellate Body:

We do not see the clear distinction drawn by China between 'content' and 'goods'. Neither do we consider that content and goods, and the regulation thereof, are mutually exclusive. Content can be embodied in a physical carrier, and the content and carrier together can form a good. For example, in Canada-Periodicals, the Appellate Body found that 'a periodical is a good comprised of two components: editorial content and advertising content. Both components can be viewed as having services attributes, but they combine to form a physical product-the periodical itself.' ... We therefore share the view [of the United States] that China's arguments 'are premised on an artificial dichotomy between film as mere content (which China contends is not a good) and the physical carrier on which content may be embedded (which China views as a good). ${ }^{, 33}$

Accordingly, by rejecting the 'mutual exclusiv[ity]' of 'contents' (which it viewed "as having services attributes") and 'goods,' and by rejecting the 'artificial dichotomy' between the 'intangible content' of films and the physical carrier of films, it appears that the WTO case law does not recognise any goods/services dichotomy.

Third, existing WTO case law further seems to provide some guidance on determining whether a product is a 'good.' In this regard, one should first recall that 'tangibility' is not a touchstone for such a determination. In US-Softwood Lumber IV (2004), the Appellate Body commented that "the ordinary meaning of the term "goods" [...] includes items that are tangible and capable of being possessed." "Th 'includes' used by the Appellate Body suggests that 'tangibility' is only indicative (and

31 Appellate Body Report, China - Measures Affecting Trading Rights and Distribution Services for Certain Publications and Audiovisual Entertainment Products, WTO Doc. WT/DS363/AB/R (adopted Dec. 21 2009), ๆף 193-195, available at https://www.wto.org/english/tratop_e/dispu_e/cases_e/ds363_e.htm (last visited on Apr. 23, 2019).

32 Id. at 194.

33 Id. 195.

34 Appellate Body Report, United States - Final Countervailing Duty Determination with respect to certain Softwood Lumber from Canada, WTO Doc. WT/DS257/AB/R (adopted Feb. 17 2004), ๆ 59, available at https://www.wto.org/ english/tratop_e/dispu_e/cases_e/ds257_e.htm (last visited on Apr. 23, 2019). 
not conclusive) for a product to be classified as a 'good.'

Further, in China-Publications and Audiovisual Products (2009), the Appellate Body observed that "the term 'product' is used [in China's GATS Schedule] to refer to both tangible and intangible goods, as well as services." 35 The expression 'intangible goods' clearly indicates against the use of 'tangibility' as a touchstone for determining whether a product is a 'good.'

More recently, the Panel in EU-Energy Package (2018), in the context of ruling that natural gas is a 'good,' observed:

\begin{abstract}
Natural gas is obviously not 'tangible', i.e., '[a]ble to be touched; discernible or perceptible by touch; having material form' (Shorter Oxford English Dictionary, 6th edn, A. Stevenson (ed.) (Oxford University Press, 2007), Vol. 2, p. 3175), but is unquestionably a 'good'. As noted by the European Union, natural gas is classified under the Harmonised System, which covers only goods...
\end{abstract}

Summarising the above, two observations can be made. First, 'tangibility' plays no defining role in the classification of products as goods or services. Second, the following factors may be of some relevance in assessing whether a product is a good: (a) whether the product is classified under the Harmonized System (HS); ${ }^{37}$ (b) whether the components of the product 'combine to form a physical product," 38 and (c) whether the product (or its 'like' products) is described by a Member's domestic law as a good. ${ }^{39}$

\title{
B. Are Current GATT/GATS Obligations Sufficient?
}

There is severe academic criticism to the insufficiency of current WTO disciplines regulating AI-powered products. Mitchell and Mishra, for example, argued that GATS obligations are 'insufficient' in a digital age, since: (a) they are contingent upon

35 Appellate Body Report, supra note 33 at 9364.

36 Panel Report, European Union and its Member States-Certain Measures relating to the Energy Sector, WTO Doc. WT/DS476/R (circulated Aug. 10 2018), 77.268 (n. 604), available at https://www.wto.org/english/tratop_e/dispu_e/ cases_e/ds476_e.htm (last visited on Apr. 23, 2019). The Panel further observed that "Russia does not argue otherwise [against this argument]." See id.

37 Id. One should recall that in China - Publications and Audiovisual Products, the Appellate Body referred approvingly to the US' argument that the product in concern (i.e., that a physical film reel containing content) is a good since, inter alia, it was "treated as a good under China's own tariff regime" See Appellate Body Report, supra note 31 at 195.

38 Id.

39 Id. Here, the Appellate Body observed that the product in concern was "treated as a good under [the Respondent]'s own tariff regime." 
specific commitments/exemptions; ${ }^{40}$ and (b) the Services Sectoral Classification List (the 'W/120') is 'outdated. ${ }^{41}$ Burri argued that the 'pre-Internet origin' of existing classification schemes are ambiguous, thereby leaving room for digital services to be classified as 'audiovisual services' in respect of which many Members have made few commitments. ${ }^{42}$ Mitchell and Hepburn argued, in the context of crossborder data transfer restrictions, that such measures' classification under the GATS is "problematic" ${ }^{43}$ and is potentially relevant to "numerous service sectors."

A closer examination of the WTO law reveals that the above comments may be overstated. First, it is imprudent to assume that trade in AI-powered products is only governed by the GATS rules. As discussed in Part III.A, trade in AI-powered products could be regulated under the WTO law both as goods and as services. In fact, for some AI-powered products (such as self-driving cars or drones), it might be more conceivable for the WTO Members to trade their final forms as goods, rather than as their supporting AI programmes as services.

Second, the 'W/120,' which is of a pre-internet origin, may indeed be 'outdated,' but it is capable of being interpreted under the Vienna Convention on the Law of Treaties ("VCLT") to include AI-powered services as if they are powered by conventional means. Thus, in US-Gambling (2005), the Appellate Body interpreted that gambling and betting services fall under the category of "Sporting and other recreational services" in the US schedule. ${ }^{45}$ The Appellate Body paid scant attention to whether such services were delivered through the internet or otherwise. Accordingly, it would seem that AI-powered services, 'new' as they might appear to be, are likely to be categorised under the W/120 as their conventional counterparts. For example, an AI-powered map/navigation programme for smart phones is likely to be categorised under 'map-making services' within W/120.

Summarising the above discussion, it can be seen that current WTO law, as exemplified through its case laws, seems to indicate that AI-powered products cannot escape existing WTO disciplines on trade in goods and trade in services, by virtue of either the involvement of AI or the perceived goods/services dichotomy.

40 A. Mitchell \& N. Mishra, Data at the Docks: Modernizing International Trade Law for the Digital Economy, 20 VAND. J. ENT. \& TECH. L. 1089 (2018).

41 Id. at 1090.

42 Burri, supra note 8 at 85.

43 Mitchell \& Hepburn, supra note 7 at 197.

44 Id. at 199.

45 Appellate Body Report, United States-Measures Affecting the Cross-Border Supply of Gambling and Betting Services, WTO Doc. WT/DS285/AB/R (adopted Apr. 20, 2005), ๆ 213, available at https://www.wto.org/english/tratop_e/ dispu_e/cases_e/ds285_e.htm (last visited on Apr. 23, 2019). 
For example, assume that AI-powered self-driving cars, which operate or update their navigation systems by exchanging data with overseas servers, ${ }^{46}$ are commercialised and traded internationally. Trade in AI-powered cars, however, could not escape the current WTO disciplines regulating conventional cars (as goods) due to the involvement of AI "behind the scene." Further, AI-powered selfdriving cars are likely to be assigned with the same commodity codes as conventional passenger cars under the current tariff systems of many (if not all) WTO Members, and accordingly subject to the same tariff barriers of conventional cars. Finally, since the navigation systems of AI-powered cars are supported by imported data (which are services), it is likely that measures regulating trade in such cars would also attract the WTO disciplines regulating trade in (for example) "supporting services for road transport services" (CPC 744).

As another example, assume that an AI-powered online programme offering accounting services, which provides essentially the same services as the ones that human accountants can deliver online, is commercialised and made available internationally. Such a programme still cannot escape the current WTO disciplines regulating conventional accounting services simply because of the involvement of AI (and the lack of human involvement). Accordingly, it can be seen that in the context of services, the involvement of AI cannot prevent the application of existing WTO disciplines.

\section{Whether existing WTO Law Is Capable of Maintaining Any Balance between Trade Facilitation and a Range of Non-Trade Value that its Members May Seek to Protect?}

As discussed in Part II.B above, the development or use of AI-powered products may attract controversies relating to non-trade values. The core of such controversies appears to be trade liberalisation of AI-powered products, on the one hand, and protection of public moral or national security concerns, on the other hand. Such tension may further compel a Member to restrict the importation of AI-powered products, thus raising questions as to whether such restrictions are permissible under the WTO law.

If the restriction consists an import restriction on AI-powered products as goods (such as self-driving cars), such a restriction could be then challenged under the two

\footnotetext{
46 J. Anderson et al., Autonomous Vehicle Technology: A Guide for Policymakers xxi (2016). It states that automated vehicles use various forms of communication, including 'cloud-based resources,' 'continually updated maps' and 'software updates.'
} 
non-discriminatory principles under the GATT 1994, namely the most-favourednation (MFN) treatment obligation and the national treatment (NT) obligation, or under market-access obligations such as the general prohibition of quantitative restrictions. Nevertheless, the restricting Member might argue that the goods powered by what it perceives as 'unethical AI' are not 'like' products with goods powered by 'ethical AI' due to differences in consumer preferences. At any rate, it seems that the restricting Member would be entitled to invoke the public morals justification under Article XX(a) of GATT 1994, which offers some discretion for Members to restrict trade in AI-powered goods based on their own standard of public morals. A Member may (at least in theory) also invoke the security exception under Article XXI of GATT 1994 with the aim of protecting its national security, yet in practice such an invocation might be restrained by policy concerns.

A similar rationale could apply if a Member places an import restriction on an AI-powered service, such as navigation services that power self-driving cars, or AI-powered accounting services. Provided that the restricting Member has made commitments in the relevant conventional service sectors, it is likely that GATS-based non-discrimination and market access obligations would also apply to any mirroring AI-powered services. Alternatively, such restrictions may also be justified under public moral/order and security exceptions under Articles XIV(a) and XIV bis GATS.

\section{The Ways Forward the WTO Disciplines on Trade in AI-powered Products}

It would appear, from the above discussion, that general WTO disciplines applying to conventional goods and services are not barred from applying to equivalent AIpowered goods and services. Accordingly, it would be safe to say that the WTO law provides for at least some disciplines on trade in AI-powered products.

This does not mean that further development or clarification of such disciplines is unnecessary. However, one should recall that although academic efforts have been made for new international treaties to be negotiated regarding trade in AI-powered products, such efforts have so far resulted in little actual progress; this appears to be even so in the most recent WTO negotiations on trade-related aspects of e-commerce.

In short, it would be more practical for the WTO Members who are unsatisfied with the current WTO disciplines on trade in AI-powered products to negotiate 
an adjustment of their GATT/GATS ${ }^{47}$ commitments and concessions, or otherwise the classification systems of goods and services that are currently being used. For example, Members might not have envisaged the advent of self-driving cars when they negotiated their concessions and commitments regarding trade in conventional cars. Yet, such a phenomenon is not new. In US-Gambling (2005), the US might not have had online-based gambling services in mind when it made the commitment on "Sporting and other recreational services." Further, Members could continue to seek clarification or development of the WTO law regarding trade in AI-powered products from case law that will arise in the future.

\section{Conclusion: Old Wineskin and New Wine}

The tardiness of the WTO law in responding to technological advancements has drawn criticism from the academic community. Some criticism, however, seems to be overstated in respect of trade in AI-powered products. A closer reading of the WTO case law indicates that at least some principles are applicable to such trade.

First, there is no goods/services dichotomy under the WTO law; existing case law already provides some guidance in classifying AI-powered products as goods and/ or services, possibly by following their closest conventional counterparts. Second, although the 'W/120' pre-dates the internet, it can be interpreted under the VCLT to include AI-powered services as if they are powered by conventional means. Third, existing general and security exceptions afforded by GATT 1994 and GATS, especially the 'public morals' and security exceptions, provide the WTO Members with some discretion to establish trade restrictions against AI-products that are created by, or used for, practices that they consider to be incompatible with their moral, ethical or national security standards. Accordingly, while existing WTO law is far from perfect, it can at least provide some disciplines on trade in AI-powered products, and can be further developed through case law in the future.

47 This may also include any concessions or commitments that were made in the accession protocols (if any). 
